\title{
Market Segmentation as A Marketing Strategy to Achieve The Market of The Company Market
}

\author{
Widi Winarso ${ }^{1}$, Rorim Panday ${ }^{2}$, Adelina Suryati ${ }^{3}$ \\ \{widi.winarso@dsn.ubharajaya.ac.id ${ }^{1}$,indripan@gmail.com², adelina.suryati@dsn.ubharajaya.a \\ c. $\left.i^{3}\right\}$ \\ 1,2 Economic Faculty, Bhayangkara Jakarta Raya University, \\ Jl. Perjuangan, Marga Mulya, Bekasi Utara, Jawa Barat, Indonesia \\ ${ }^{3} \mathrm{PhD}$ Student of Economic Department, Trisakti University, Grogol, Jakarta Barat, Indonesia
}

\begin{abstract}
One of the strategies applied by the company to dominate the market amid fierce competition is to target the target market (market segmentation). Market segmentation is to divide the market into subdivisions of groups of people and institutions as consumers and customers who have similarities in responding to products and services sold or marketed by companies. The research method used in scientific research is a method of literature review, namely the method by collecting data by reading books and literature related to the subject matter. This study discusses the extent to which market segmentation strategies play a role for companies in capturing market share. Finally, it can be concluded that the strategy in identifying and selecting the target market is very important in capturing the increasingly fierce market share of competition.
\end{abstract}

Keywords: . Market Segmentation, Market Share

\section{Introduction}

The overall marketing strategy objective must always be focused on sales estimates for the year in question as well as for a longer period of time. This sales estimate is used as a catalyst by every other functional field in estimating its needs for the year in question.

The marketing process is a sequential process. This process begins with the identification of needs in order to determine the person or situation that will become the company's potential market. Markets that are defined in such a manner are permanent and stable. The use of market concepts still wants the determination of the competition framework and allows monitoring of function and market performance indicators (categories): size, variation, market share.

Defining the market is the basis of the strategy of segmentation, targeting and positioning and subsequently becomes the basis of definition if the context called the market has been defined. Segmentation continues to create hyper-fragmented markets that reduce the chances of success for new products.

The marketing concept emphasizes that the key to achieving the organizational goals set is that the company must be more effective than competitors in creating, delivering, and communicating customer value to selected target markets

\section{Understanding of Marketing}

Marketing is the most important part that relates to the market because the existing market is the buyer's market where the sale and purchase transaction depends on the buyer's own 
decision. So that the existing market is very influenced by the behavior of consumers and the important thing is that the company that offers goods can only follow the wishes of consumers and how to deal with competitors - company competitors who create similar goods.

Thus, if we hear the word marketing, we will connect various activities of sales, trading, distribution, pricing and so on. Some understanding of marketing are according to Philip Kotler [1] is is a social process in which individuals and groups get what they need and want by creating, offering, and freely exchanging valuable products with other parties. Philip and Duncan [2] includes all steps that are used or needed to place goods - tangible goods to consumers. American Marketing Association.[3] includes the implementation of commercial business activities directed at the flow of goods and services from producers to consumers.

The main functions of marketing activities are: 1). To provide information about the products sold by the company. 2). To influence consumer buying decisions. 3). To create the economic value of an item.

For the managerial definition, marketing is often described as the art of selling products, but some of us are surprised to hear that the most important part of marketing is not sales. That sale is only a small peak of marketing icebergs. Peter Drucker [4], a leading management theorist, said the following:

One can assume that there will always be a need for sales everywhere. The marketing goal is to know and understand the customer in such a way that the product or service matches the customer and then sells himself. Ideally, marketing should produce a customer who is ready to buy. All that is needed next is to provide products and services.

\section{a. Market Segment}

Market segments consist of large groups that can be identified in a market with desire, purchasing power, geographical location, buying behavior, and similar buying habits. For example, a car company might identify four broad segments; Car buyers who are looking for basic transportation, those who are looking for high performance, those who are looking for luxury, and those who are looking for comfort. Segment marketing offers several benefits compared to mass marketing. Companies can create products or services that are more aligned and charge appropriate prices for certain target groups. The choice of distribution channels and communication channels is much easier. Companies may also face fewer competitors in certain segments. Market segments [5] include:

1. Niche marketing

Is a group that is defined more narrowly, especially small markets whose needs are not well served. Marketers usually identify niches by dividing a segment into subsegments or by defining a group that seeks a combination of special benefits that are different from those sought by other groups.

2. Local Marketing

Marketing is tailored to the needs and desires of local customer groups (trading area, surrounding environment, even individual talks). Citibank provides its branched banking service mix, which depends on the demographic conditions surrounding the bank. Those who support the location of the company's marketing consider national ads to be futile because they fail to attract local targets. Those who oppose local marketing argue that they can increase production and marketing costs by reducing economies of scale. Logistical problems are great if companies try to meet the requirements of different regional and local markets. And the overall image of the company will wear off if the products and messages differ in different places.

3. Individual marketing 
The highest level of segmentation leads to "single segment" marketing according to order (customized marketing), or marketing one on one. For centuries consumers were served as individuals, such as tailors making clothes, cobblers designing shoes for individuals. Most business-to-business marketing is currently made to order, where manufacturing companies will adjust the offerings, logistics and financial requirements for each customer. Mass order manufacturing is the ability to prepare individually designed products and communications on a mass basis to meet each customer's requirements.

Today more customers take more individual initiatives in determining what and how to make a purchase. They enter the internet, look for information and evaluations about product and service offers, dialogue with product suppliers, users, and critics, and choose the best offer. Marketers will still influence the process but in a new way. Marketers must provide tollfree telephone numbers, and email addresses so that potential and actual buyers can easily contact them to ask questions, suggestions, and complaints.

\section{b. Market Segmentation Pattern}

Market segments can be formed in many ways. One of them is by identifying preference segments. Suppose an ice cream buyer is asked how much he appreciates the sweetness and content of ice cream as two product attributes. [6] Three different patterns can appear:

1. Homogeneous preferences

Shows a market where all consumers roughly have the same preferences. The market does not target natural segments. We will predict that the existing brands will be similar and clustered amid the sweet scale and cream content.

2. Spread preferences

Consumer preferences are scattered throughout the field which shows that consumer preferences vary widely. The first brand that enters the market is likely to take a position in the middle, attracting most people. Brands in the middle will minimize the total amount of consumer dissatisfaction. The second competitor can move next to the first brand and fight to gain market share. Or they can be located in a corner to attack a group of customers who are not satisfied with the brand in the middle. If some brands are in the market, they are likely to take positions throughout the field and show real differences to meet differences in consumer preferences.

3. Group preferences

The market may show different preferences, which are called natural market segments. The first company on the market has three choices. He can take a position in the middle, hoping to attract all groups. He can take a position in the largest market segment (concentrated marketing). He can develop several brands, and each brand is positioned in a different segment. If the first company only develops one brand, competitors will enter and introduce the brand in the other segment.

\section{c. Company Market Share}

Market Share is a marketing strategy that involves dividing a broad target market into subsets of consumers, businesses, or countries that have, or are considered to have, general needs, interests, and priorities, and then design and implement strategies to target them. Market segmentation strategies are usually used to identify and subsequently determine target customers and provide supporting data for elements of a marketing plan such as a position to achieve the objectives of a particular marketing plan. Businesses can develop product 
differentiation strategies, or differentiated approaches, which involve specific products or product lines depending on the specific demands and attributes of the target segment.

There is also a simple interpretation of market share, namely the percentage of total sales of a company (from all sources) with total sales of services or products in the industry.

\section{Method}

The method used by the author in collecting and processing data is a qualitative method, namely library research, and observation. Where this method is by collecting data by reading books and literature as well as other articles from the internet related to the subject matter. Even this research method uses the results of a panel discussion about the discussion of the problems that occur so that the data - data that is still valid and can be justified

\section{Market Segmentation Procedure}

Here will be discussed three steps to identify market segments [7], namely:

1. Stage of Survey

This method is carried out by conducting interviews to look for explanations and form focus groups to get an understanding of consumer motivation, attitudes, and behavior. Next, the researcher prepares an official questionnaire to gather data on the attributes and ranking of importance of the attribute. Brand awareness and brand ranking, product usage patterns, attitudes toward product categories, demographic, geographical, psychographic, and media graphics conditions of respondents

2. Analysis Phase

Researchers conduct a factor analysis of the data to dispose of the highly correlated variables, then the researcher applies group analysis to produce the maximum number of different segments.

3. Formation Stage

Each group is formed based on differences in attitudes, behaviors, demographics, psychographics, and media patterns, each segment can be named based on its dominant nature.

\section{Basic Consumer of Market Segmentation}

Some researchers try to form segments by observing consumer characteristics, including geographical, demographic and psychographic characteristics. Then they check whether the consumer segments show different product needs or responses. According to Kotler (Kotler 2000), market segmentation is divided into:

1. Geographical Segmentation

Geographical segmentation is a segmentation that bases market division into different geographical units such as countries, states, regions, provinces, cities or household environments. The research from Zumrotul Halimah [8] entitled "The Influence of Market Segmentation on the Sales Volume of Muslim Clothing Products (2017), explains that geographical segmentation partially has a positive relationship, and has a significant effect on the Muslim fashion sales volume of Ummi Collection. Another study is according to Nurthajani [9] with the title Effect of Market Segmentation on Telkom Speedy Product Purchase Decisions at PT Telekomunikasi Indonesia (2017), explaining the results of the research are partially, market segmentation on the four components namely geographic, demographic, 
psychographics and behavior have a significant effect on purchasing decisions. The highest beta coefficient comes from psychographics.

2. Demographic Segmentation

Demographic segmentation is a segmentation where markets are divided into groups based on demographic variables such as age, family size, family life cycle, gender, income, education, religion, race, generation, citizenship, and social class. Variables - demographic variables are the most popular basis for distinguishing groups of customers. According to the study of Zumrotul [8], it was explained that the results of the study on the influence of demographic segmentation on sales volume that demographic segmentation partially had a positive relationship, and significantly influenced the sales volume of Muslim clothing Ummi Collection. Another study is according to Ilmi, Ahmad Bahari [10]. "Analysis of the Effect of Market Segmentation on Purchasing Decisions of Telkom Speedy Products at PT. Indonesian Telecommunications Branch Kediri ".The results of his research are show in multiple regression analysis equation as followed:

$$
\mathrm{Y}=2,524+0,191 \mathrm{X} 1+0,073 \mathrm{X} 2+0,331 \mathrm{X} 3+0,365 \mathrm{X} 4+0,05 .
$$

From the results of multiple linear regression analysis the results show that Geographic variables (X1), Demographic (X2), Psychographic (X3), and Behavior (X4), influence the purchasing decisions of Telkom Speedy $(\mathrm{Y})$ products in a linear way. And the most influential variable is Behavior (X4) with a coefficient of 0.365 . The coefficient of determination $\left(\mathrm{R}^{2}\right)$ is 0.345 , meaning that all derivative variables of strategic segmentation have a joint contribution of $34,5 \%$ to the dependent variable (Y), namely the purchasing decision. The remaining $65.5 \%$ is influenced by other factors not included in the study. The following is how certain demographic variables have been used to segment the market:

a. Age and life cycle stage [11]

b. Gender

c. Income

d. Generation

e. Social class

3. Psychographic Segmentation [12]

Is a segmentation that divides market share based on lifestyle or personality values. People in the same demographic group can show very different psychographic images.

a. Lifestyle

b. Personality

c. Value

From the results of Zumratul [8] research on the effect of psychographic segmentation on sales volume that psychographic segmentation partially has a positive relationship, and has a significant effect on the sales volume of Muslim clothing Ummi Collection. Other research according to Nurtjahjani [9] produces conclusions that are not much different, market segmentation has a significant influence on seizing market share (sales volume) 


\section{a. Determination of the Target Market}

After the company has identified its market segment opportunities, it must evaluate various segments and determine how many and which segments will be targeted. The things to do are:

1. Evaluating Market Segments

In evaluating different market segments, companies must pay attention to two factors, namely the attractiveness of the overall segment and the objectives and resources of the company.

2. Choosing a Market Segment

\section{b. Calculating Market Share [13]}

a. Determine the period to be examined in each company analyzed. Check sales in a certain period to make sure the comparison to be made is valid. You can check sales throughout the quarter, one year, or several years.

$$
\text { Period to examine }=\text { a quarter } / \text { a year } / \text { several years }
$$

Calculate total revenue or total sales. All public companies must issue quarterly or annual financial reports. These reports will include all company sales figures, and may also be accompanied by an explanation of the sale of a particular product or service in the financial statement footnote.

Total revenue $/$ Total sales $=$ firm sales + specific product sales + service type sales

If the company examined sells various types of products and services, do not use total sales of all products and services to be examined. Look for information on selling certain products or services in financial statements.

b. Look for total market sales (total market sales). This number shows the sales (or income) of all companies to a particular market.

\section{Total Market Sales = Sales by Big Company + Sales by Small Company}

The total amount of market sales can be found through public reports from the relevant Industry Trade Association. Some companies offer specialized information services regarding sales in the national and international market sectors.

You can also add sales of the biggest companies that sell or offer products or services to the market. If a number of companies dominate the market so that the sales figures of small companies are not significant, the sales figures for all these large companies can represent the total sales of the industry.

c. Share the company's total revenue with total industry sales on the market. The result of this division is the market share of the company. So, if a company has sales of a certain product of IDR 10,000,000, and all companies in the industry generate sales of IDR 150,000,000, the company's market share is IDR 10,000,000 / IDR $150,000,0001 / 15$.

The firm's earning a = Market share of the Company 
Industries earnings

Some people present market share in percentages, while others use ordinary fraction numbers (some people don't even simplify numbers to the smallest fractions). The form of presentation is not important, provided you understand the meaning of the number.

\section{c. Understand the limitations of market share as an indicator. [13]}

As discussed earlier, market share is a limited tool that can help develop an initial perception of a company. The value of a market share is meaningless if it only stands alone.

1. Total income as a single factor determining market share provides little information regarding the profitability of the company. If one company covers a large part of the market share but the resulting profit is small (revenue minus expenses) compared to other companies, market share is a less substantial indicator of the success of the company now and in the future.

2. Market share can provide more market-related information than companies. Some markets have been consistently dominated by one or a small group of companies, and only a few changes have occurred over the past few years. Monopoly power is almost impossible to beat by other companies in the market so analysis of market share will only confirm this fact. However, small companies are still able to achieve success and have good profitability.

\section{Conclusion}

From various existing studies, it can be concluded that market segmentation plays a very dominant and significant role. Establishing a target marketing strategy through market segmentation is an important aspect of any marketing plan. The aim is to clearly identify and describe market segments, target specific segments, and then show precisely the differentiated benefits that will be stressed. Absolut market segmentation is needed so that the marketing program that will be carried out by the company becomes more focused on trying to capture available market share.

\section{References}

[1] Kotler, Manajemen Pemasaran Jilid 2. 2013.

[2] P. J. Bergmann and D. J. Irschick, "Vertebral evolution and the diversification of squamate reptiles," Evolution (N. Y)., 2012.

[3] F. Cochoy, "The American Marketing Association," J. Hist. Res. Mark., 2014.

[4] F. E. Webster, "Marketing is management: The wisdom of Peter Drucker," J. Acad. Mark. Sci., 2009.

[5] J. B. E. M. Steenkamp and F. Ter Hofstede, "International market segmentation: Issues and perspective," Int. J. Res. Mark., 2002.

[6] A. Sandy, S. Alumni, U. Ma, and C. Malang, "Membuat Segmentasi Berdasarkan Life Style (Gaya Hidup)," Membuat Segmentasi Berdasarkan Life Style, 2013.

[7] A. Carrissa, "Penerapan Customer Relationship Management (CRM) Sebagai Upaya Untuk Meningkatkan Loyalitas Pelanggan,” J. Adm. Bisnis, 2014.

[8] Z. Halimah, The Influence of Market Segmentation on the Sales Volume of Muslim Clothing Products. Indonesia, 2017.

[9] M. Fullchis Nurtjahjani, Asminah Rachmi, "Pengaruh Segmentasi Pasar Terhadap 
Keputusan Pembelian Produk Telkom Speedy Di Pt Telekomunikas Indonesia Cabang Malang," J. Adm. dan Bisnis, vol. 11, Nomor, pp. 107-114, 2017.

[10] A. B. Ilmi, Analisis Pengaruh Segmentasi Pasar Terhadap Keputusan Pembelian Produk Telkom Speedy di PT Telekomunikasi Indonesia Cabang Kediri. Akademik, 2013.

[11] A. Calha, "Universidade de lisboa," 2014.

[12] E. B. Lewis, "A gene complex controlling segmentation in Drosophila," in Genes, Development, and Cancer: The Life and Work of Edward B. Lewis, 2007.

[13] W. Winarso, Analisa Strategi Pemasaran pada Perusahaan Distributor PT. Maya Muncar. Akademik, 2007. 